\title{
Determination of Lethal Dose for Gamma Rays Induced Mutagenesis in Butter Bean (Phaseolus lunatus L) Variety KKL-1
}

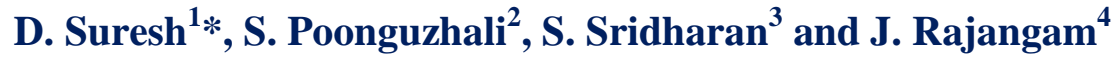 \\ ${ }^{1}$ Department of Horticulture, Thanthai Roever Institute of Agriculture and \\ Rural Development, Perambalur, India \\ ${ }^{2}$ Department of Crop Improvement, Thanthai Roever Institute of Agriculture \\ and Rural Development, India \\ ${ }^{3}$ Department of Horticulture, National Research Centre for Banana, Trichy, India \\ ${ }^{4}$ Department of Horticulture, Horticulture Research Station, Kodaikanal, India \\ *Corresponding author:
}

\begin{tabular}{|c|c|}
\hline & A B S T R A C T \\
\hline Keywords & \multirow{4}{*}{$\begin{array}{l}\text { In the present studies treated the seeds using gamma rays different does } 10 \\
\mathrm{kR} \text { to } 100 \mathrm{kR} \text { each treatment using } 50 \text { seeds. The percentage of seed } \\
\text { germination ranges from } 0 \text { per cent to } 52 \text { per cent with different does of } \\
\text { gamma rays in butter bean variety KKL- } 1 \text { as compared to } 86 \text { per cent } \\
\text { control. The different in seed germination are statistically significant. The } \\
\text { LD50 value was found at } 10 \mathrm{kR} \text { for seed germination. The percentage of } \\
\text { survival was } 81 \text { per cent in control while it are significant range from } 0 \text { per } \\
\text { cent } 100 \mathrm{kR} \text { to } 48 \text { per cent } 10 \mathrm{kR} \text { of gamma rays in butter bean variety } \\
\text { KKL-1. The LD50 value for seedling survival has to fixed at } 10 \mathrm{kR} \text {. }\end{array}$} \\
\hline $\begin{array}{l}\text { Gamma ray, } \\
\text { Lethal dose, } \\
\text { Butter bean, } \\
\text { KKL-1. }\end{array}$ & \\
\hline Article Info & \\
\hline $\begin{array}{l}\text { Accepted: } \\
\text { 15 February } 2017 \\
\text { Available Online: } \\
10 \text { March } 2017\end{array}$ & \\
\hline
\end{tabular}

\section{Introduction}

Induced mutation plays a significant role in the crop improvement of horticultural crops. It is an important tool for induction of variation in quantitative and qualitative characters. It can be a supplement to conventional breeding methods when it is desired to improve one or two characters in a well adapted variety.

Much progress has been made in generating superior genotype with favourable attributes through induced mutations.
It is much more useful in crop where cross incompatibility mechanisms exist. Creation of variability in highly self pollinated crops like peas and beans is very difficult by heterosis breeding due to high crossing barrier and poor seed setting.

Butter beans (Phaselous lunatus L) belongs to the family Leguminaceae. KKL1 butter beans is a selection from a local type collected of Vilpatti. It is a pole type and bean growing upto a height of $2.42 \mathrm{~m}$. The pods are cluster $11.6 \mathrm{~cm}$ long and beans are 5 to 6 numbers 
per pod. The pods are green when immature, turning creamy yellow with brownish purple streaks on the surface at maturity. The seeds are bold, globular snow white in color with excellent cooking quality. The variety is suited for hilly regions of Tamil Nadu with attitude longest from $1200 \mathrm{~m}$ to $2200 \mathrm{~m}$ above MSL. The crop will be ready for first harvest from 100 days after sowing and the harvest continues upto 140 days with a potential yield of 3.47 tonnes of mature pods per hectare in three or four pickings. The present investigation is to study the effect of gamma irradiation in KKL-1 in evolving a mutant with some specific for desirable traits.

\section{Materials and Methods}

The present investigation was carried out during 2012-13 on the "Studies on induced mutation in butter bean (Phaseolus lunatus L) var. KKL-1 through gamma rays at the Department of Vegetable crop, Horticultural College and Research Institute, Tamil Nadu Agricultural University, Coimbatore.

Field trial are conducted in the poly house and open field at Horticultural Research Station, Kodaikanal, which is geographically situated between $10^{\circ} 24^{\prime} \mathrm{N}$ latitude and $77^{\circ} 48^{\prime} \mathrm{E}$ longitude at an altitude of $2225 \mathrm{~m}$ above mean sea level. The mean minimum and maximum temperature during the study period between $2.5^{\circ} \mathrm{C}$ and $30^{\circ} \mathrm{C}$ respectively and the relative humidity was 40 to 100 per cent. The soil of the experimental field is loamy silt with a $\mathrm{pH}$ of about 5.85

\begin{tabular}{l}
\hline Characters \\
Pedigree \\
Organisation of release \\
Habit \\
Maturity \\
Pod yield
\end{tabular}

Physical mutagen viz. gamma rays (ionizing radiation) the gamma treatments were given by using the 1000 curie Cobalt-60 Gamma cell 900, located at the Centre for Plant Breeding and Genetics (CPBG), Tamil Nadu Agricultural University, Coimbatore, where cobalt- 60 serves as source of gamma rays.

\section{Results and Discussions}

\section{Determination of $\mathbf{L D}_{\mathbf{5 0}}$ value}

For any induced mutagenesis programmed, it is necessary to fix the $\mathrm{LD}_{50}$ value based on which further doses will be fixed for the treatment and study of larger population. The $\mathrm{LD}_{50}$ value varies according to crop species, varieties, seeds or other planting materials, nature of treatment, method of raising, climate, cultural practices and other

\section{KKL-1 Butter bean \\ Selection from a local type \\ HRS, TNAU, Kodaikanal \\ Pole type $(2.42 \mathrm{~m})$ \\ 140 days \\ 3.47 tonnes $\mathrm{ha}^{-1}$}

parameters (Singh, 1994). The LD 50 value was found to be $10 \mathrm{kR}$ in germination and seedling survival. Whereas, a slight variation is noticed between different varieties of same spices depends on size, maturity, hardiness and moisture content at the time of treatment (Alikhan et al., 1975 in redgram and Krishnaswami et al., 1977 in greengram). In the present study, based on the germination on $8^{\text {th }}$ day and survival on $30^{\text {th }}$ day, LD 50 values of gamma rays have been arrived for KKL-1 butter bean The effect of various doses of gamma rays varied from 0 to $100 \mathrm{kR}$ on seed germination and seedling survival are presented in Table 1 and illustrated in Figure1and Figure2. The percentage of seed germination ranged from 0 per cent to 52.00 per cent with different doses of gamma rays in butter bean variety KKL-1 as compared to 86.00 per cent in control. The differences in 
seed germination are statistically significant. The $\mathrm{LD}_{50}$ value was fixed as $10 \mathrm{kR}$ for seed germination in butter bean variety KKL- 1 . The percentage of seedling survival was 81.00 per cent in control while it are significant ranged from 0 per cent $100 \mathrm{kR}$ to $48.0010 \mathrm{kR}$ of gamma rays in butter bean variety $\mathrm{KKl}-1$. The $\mathrm{LD}_{50}$ value for seedling survival has been fixed as $10 \mathrm{kR}$. Slightly higher doses of gamma rays at $55 \mathrm{kR}$ for germination and 50$55 \mathrm{kR}$ for seedling survival were reported in cowpea variety CO-VU-623 by Thirugnanakumar (1986). Gunasekaran (1992) reported that the $\mathrm{LD}_{50}$ value for germination was found to be $50-55 \mathrm{kR}$ and for survival $35-40 \mathrm{kR}$ for the cowpea variety $\mathrm{CO}$ 4 The lower dose of $\mathrm{LD}_{50}$ butter bean showed the sensitivity of the crops to physical mutagen i.e., gamma rays. Drastic reduction in mean survival per cent after $10 \mathrm{kR}$ were pruned that the butter bean variety KKL-1 was highly sensitive to gamma rays and chance of creating variability is enormous.

Gaul (1970) reported that the physical and chemical mutagens induced physiological damages causing primary injury and factor mutations with chromosomal aberrations in the biological material in $\mathrm{M}_{1}$ generation. A quantitative determination of $\mathrm{M}_{1}$ altered configurations will help to predict the efficiency of mutagens. In the present investigation, variability in $\mathrm{M}_{1}$ and $\mathrm{M}_{2}$ generations were estimated under field conditions. There was a reduction in the seed germination with increase in doses of gamma rays in $\mathbf{M}_{1}$ and $\mathbf{M}_{2}$ generations. These are in conformity with the results obtained from earlier studies in lima bean (Mensah and Eruotor, 1993 and Deepthi Nair, 1996) and in soybean (Balakrishnan, 1991 and Geetha 1994 in cowpea (Thirugnanakumar, 1986; Packiaraj, 1988; Rangaswamy 1989 and Gunasekaran, 1992), in green gram (Ignacimuthu and Babu, 1988; Subramanian, 1981 and Mehetere et al., 1990) and in blackgram (Ramaswamy, 1973).

The mutagenic sensitivity of a biological material can be attributed to the level of differentiation and development of embryo at the time of treatment and also the extent of damage to the growth processes like rate of cell division, cell elongation, various stages of hormone and biosynthetic pathways as observed by Scholz and Lehman (1962). The reduction in germination percentage due to gamma rays may be attributed to either a drop in the auxin level (Gordon and Webber, 1955) or chromosomal aberrations as reported by Reed (1959) and Sparrow (1961). In the present study, a delayed seed germination was observed due to mutagenesis. A characteristic effect of irradiation in dicots seeds to be that, the affected seedlings, after the emergence of cotyledonary leaves, remain alive in the critical stage for a considerably long time (Dubinin, 1964). During this phase, there is some type of repairs or compromise that enables the seedlings to recover and carryout the regular mitotic process (Gaul, 1958).

Alternatively the seedlings are not able to overcome the radiation damage and hence they die without formation of side shoots. The seedling mortality was reported to be due to the decline of assimilation mechanism (Quastler and Baer, 1950), inhibition of auxin synthesis (Skoog, 1935), inhibition of mitosis and chromosome damage (Gunkel and Sparrow, 1961). The survival of the seedlings was also seen to reduce with increase in does of gamma rays. An inverse relationship exists between survival and doses of mutagen. Many workers have reported such a dose dependant decrease in different leguminous crops viz.,) limabean (Mensah and Eruotor, 1993 and Deepthi Nair, 1996) soybean (Balakrishnan, 1991 and Geetha, 1994) Cowpea (Palanisamy, 1975) and Rangaswamy, 1989), greengram (Krishnaswami et al., 1977; Subramanian, 1980; Ignacimuthu and Babu, 1988 and Mehetere et al., 1990) and blackgram 
(Ramaswamy, 1973). But the sudden decrease in survival after $10 \mathrm{kR}$ indicate the week tolerance limit of butter bean gamma irradiation.

Table.1 Fixing up LD 50 for gamma rays

\begin{tabular}{|c|c|c|c|c|c|}
\hline \multirow{2}{*}{$\begin{array}{l}\text { Treatme } \\
\text { nt }\end{array}$} & \multirow[b]{2}{*}{ Doses } & \multicolumn{2}{|c|}{ Germination } & \multicolumn{2}{|l|}{ Survival } \\
\hline & & $\begin{array}{l}\text { Mean } \\
\text { percentage }\end{array}$ & $\begin{array}{l}\text { Percentage to } \\
\text { control }\end{array}$ & $\begin{array}{l}\text { Mean } \\
\text { percentage }\end{array}$ & $\begin{array}{l}\text { Percentage to } \\
\text { control }\end{array}$ \\
\hline Control & & 86.0 & 100 & 81.0 & 100 \\
\hline \multirow{10}{*}{$\begin{array}{l}\text { Gamma } \\
\text { rays }\end{array}$} & $10 \mathrm{kR}$ & 52.0 & 60.46 & 48.0 & 59.25 \\
\hline & $20 \mathrm{kR}$ & 12.0 & 13.95 & 8.0 & 9.87 \\
\hline & $30 \mathrm{kR}$ & 6.0 & 6.97 & 4.0 & 4.93 \\
\hline & $40 \mathrm{kR}$ & 0.0 & 0.0 & 0.0 & 0.0 \\
\hline & $50 \mathrm{kR}$ & 0.0 & 0.0 & 0.0 & 0.0 \\
\hline & $60 \mathrm{kR}$ & 0.0 & 0.0 & 0.0 & 0.0 \\
\hline & $70 \mathrm{kR}$ & 0.0 & 0.0 & 0.0 & 0.0 \\
\hline & $80 \mathrm{kR}$ & 0.0 & 0.0 & 0.0 & 0.0 \\
\hline & $90 \mathrm{kR}$ & 0.0 & 0.0 & 0.0 & 0.0 \\
\hline & $100 \mathrm{kR}$ & 0.0 & 0.0 & 0.0 & 0.0 \\
\hline
\end{tabular}

Fig.1 Sensitivity studies -Effect of gamma rays on seed germination per cent

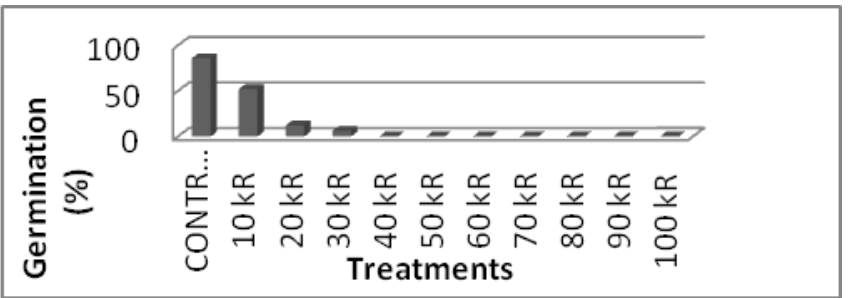

Fig.2 Sensitivity studies -Effect of gamma rays on seedling survival per cent

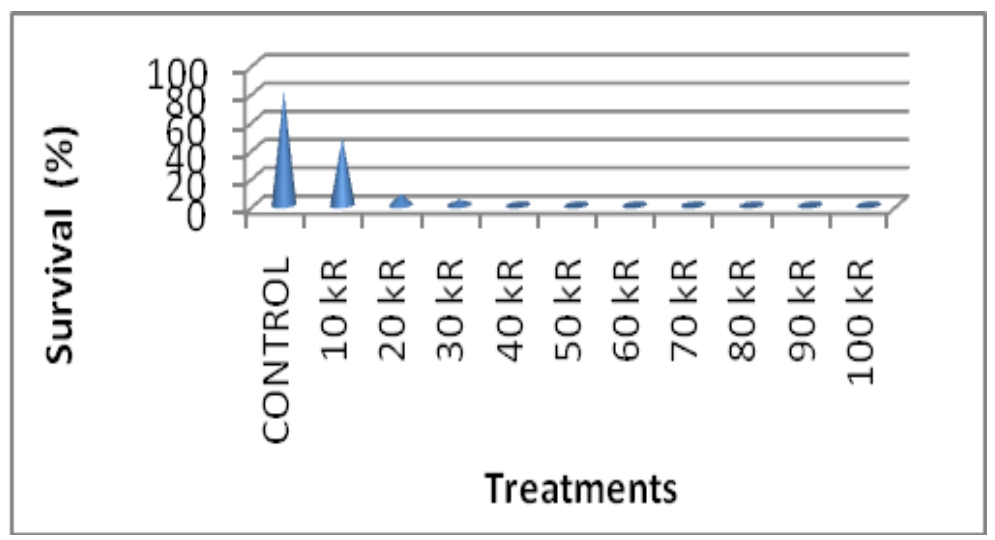


Fig.3 Plates showing germination percentage and survival percentage treated gamma rays

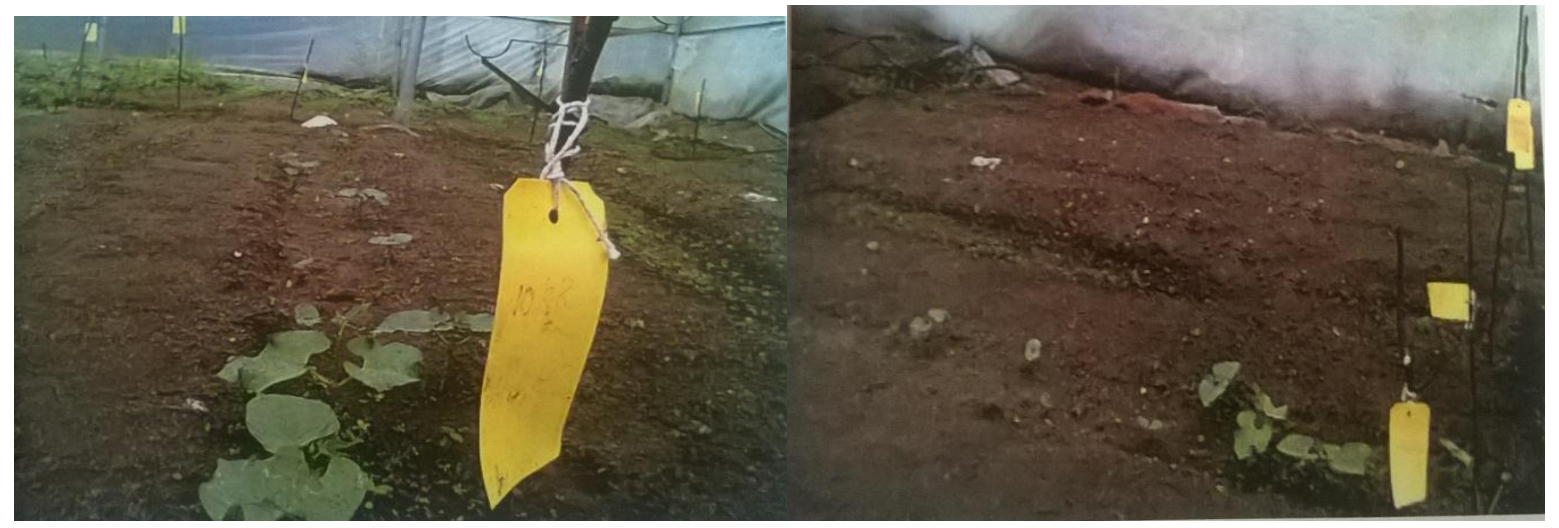

In conclusion, lethal dose for any mutagen is essential to generate highest practicable mutants with lowest damage to the plant. The LD50 dose based on survival percentage of the seedlings, after treatment with diverse doses of gamma rays for the butter bean cultivar kkl-1 were $100 \mathrm{kR}$ to $10 \mathrm{kR}$ respectively. In addition, the optimum dose based on the reduction in germination and survival was $10 \mathrm{kR}$ of gamma rays to generate maximum variability with least number of unwanted mutants. Increasing gamma rays dose decreased the germination percentage and survival percentage Generally, higher gamma rays $(20 \mathrm{kR}, 30 \mathrm{kR}, 40 \mathrm{kR}, 50 \mathrm{kR} 60$ $\mathrm{kR}, 70 \mathrm{kR}, 80 \mathrm{kR}, 90 \mathrm{kR}$ and $100 \mathrm{kR}$ ) doses higher concentration of had prominent/lethal effect on the morphological and growth characteristics of butter bean seedlings. These optimal mutagen doses determined for the butter bean genotype could be useful while formulating mutation breeding programme for enrichment of meticulous traits in butter bean.

\section{Acknowledgements}

We are grateful to the Tamil Nadu Agriculture University (TNAU), Coimbatore, Tamil Nadu (India) for awarding a research grant. We also thank to Dr. A. Jhon Joel, Professor and Head, Plant Breeding and Genetic Resource from TNAU for providing the facilities for the treatment of butter bean seeds with gamma irradiations.

\section{References}

Alikhan, W.M., N. Sivasamy and K.R. Ramaswamy. 1975. Sensitivity of two redgram (Cajanus cajan (L)Mill) strains to different mutagens. Madras Agric. J., 60(6): 406-407.

Balakrishnan, P.C. 1991. Induced mutagenesis in soybean (Glycine max (L)Merill) Ph.D. thesis, Tamil Nadu Agriculture University, Coimbatore.

Deepthi Nair, S. 1996. Studies on induced mutations in Limabean (phaseolus lunatus L ) M.Sc thesis, Tamil Nadu Agric Univ., Coimbature.

Dubinin, N.P. 1964. in "problems of Radiation Genetics" Eliver and Boyod. London, p. 445.

Gaul, H. 1958. Present aspect of induced mutations in plant breeding. Euphytica, 7: 275-289.

Gaul, H. 1970. Mutagen effects observable in the first generation. Manual on mutation breeding, IAEA, Vienna 119: 85-99.

Geetha, K. 1994. Studies on induced mutations in two distinct varieties of soybean M.Sc thesis Tamil Nadu Agric Univ., Coimbatore.

Gordon, S.A. and R.P. Webber. 1955. Studies on the mechanism of phytochrome damage by ionizing radiation I. The Radiosensitivity of Indole Acetic Acid Plant Physiol., 3: 200-210.

Gunasekaran, M. 1992. Investigation on 
induced mutagenesis in cowpea M.Sc thesis Tamil Nadu Agric Univ, Coimbatore.

Ignacimuthu, S. and N. Sakthivel. 1989. Induced chromosomal abnormality and protein sterility in Vigna radiate Cytologia, 54(1): 109-114.

Krishnaswami. S., R. Rathanaswamy and R. Veeraswamy 1977. Studies on induction of mutations in greengram through physical mutagens, Madras Agric. J., 64(2): 74-79.

Kumar, D.P., and Chaturvedi, A. 2013. Gamma radiosensitivity study on rice (Oryza sativa L.). Asian J. Plant Sci. Res., 3(1): 54-68.

Mehetere, S.S., R.B. Deshmukh and R.D. Rodge. 1990. Effect of gamma radiation on morphological attributes in the $\mathrm{M}_{1}$ generation of Mungbean. Legume Res., 13(3): 149-152.

Mensah, J.K. and P.G. Eruotor. 1993. Genetic variation in agronomic characters of limabean induced by seed irradiation, Trop. Agric., 70(4): 342344.

Nascimento, K.S., and Rego, M.M. 2015. Ethyl methane sulphonate in the generation of genetic variability in b Capsicum. Acta Hort., 1087: 249-254.

Packiaraj, D. 1988. Studies on induced mutagenesis of parent and hybrid in cowpea (Vigna unguiculata (L) Walp) M.Sc thesis Tamil Nadu Agric Univ., Coimbatore.

Quinero, C.F., B.R. Murthy and V. Zerpa. 1990. Differential growth patterns in some induced mutants of cowpea and mungbean of Venezuela, J. Genet. PI.
Breed., 48(1): 149-156.

Ramaswamy, N.M. 1973. Investigation on induced mutagenesis in blackgram Ph.D thesis Tamil Nadu Agric Univ., Coimbatore.

Rangswamy, K. 1989. Investigation on induced mutagenesis in homozygous and heterozygous genetype of cowpea (Vigna ungiculata (L) Walp) M.Sc thesis Tamil Nadu Agric Univ., Coimbatore.

Reed, J. 1959. Radiation on biology of Vicia $f a b a$ in relation to the general problem Oxford Backwell Scientific Publications.

Scholz, F. and C.O. Lehman. 1962. Die gallensle bener mutant ender saat gerste in beziehnug zur for meu marning pelti gkeit der Art Hardeum vulgare. $L S N$ kulturpf lanse, 10: 312-314.

Singh, B.D. 1994. Mutations in crop improvement In Plant Breeding Kalyani Publ., Ludhiana p 434-450.

Skoog, F. 1935. The effect of X-ray irradiation on auxin and plant growth, $J$. Cellular Camp. Physiol., 7: 227-270.

Sparrow, A.H. 1961. Type of ionizing radiations and their cytogenetic effects. In Mutation and plant breeding. Nat. Acad. Sci. Nat. Res., Council Publ., Washigton, 892: 55-199.

Subramanian, D. 1981. Effect of gamma radiation in vigna. Indian J. Genet., PI, Breed, 40(1): 187-194.

Thirugnanakumar, S. 1986. Studies on induced mutagenesis in cowpea M.Sc., thesis Tamil Nadu Agric Univ., Coimbatore.

\section{How to cite this article:}

D. Suresh, K. Indira Kumar, S. Sridharan, J. Rajangam. 2017. Determination of Lethal Dose for Gamma Rays Induced Mutagenesis in Butter Bean (Phaseolus lunatus L) Variety KKL-1. Int.J.Curr.Microbiol.App.Sci. 6(3): 712-717. doi: https://doi.org/10.20546/ijcmas.2017.603.082 